Article

\title{
Effect of Short Fermentation Times with Lactobacillus paracasei in Rheological, Physical and Chemical Composition Parameters in Cassava Dough and Biscuits
}

\author{
Samuel Longoria ${ }^{1}\left(\mathbb{D}\right.$, Juan Contreras ${ }^{2}$, Ruth Belmares ${ }^{2, *(\mathbb{C}}$, Mario Cruz $^{3, *(\mathbb{D})}$ and Mildred Flores ${ }^{3}$ \\ 1 Departamento de Nutrición, Vicerrectoría de Ciencias de la Salud, Universidad de Monterrey, Avenida \\ Morones Prieto 4500 Pte, C.P., San Pedro Garza García, Nuevo León 66238, Mexico; \\ samuel.longoria@udem.edu \\ 2 Departamento de Investigación en Alimentos, Facultad de Ciencias Químicas, Universidad Autónoma de \\ Coahuila Blvd. V. Carranza e Ing. José Cárdenas sin numero, Col. República, C.P., Saltillo, Coahuila 25280, \\ Mexico; carlos.contreras@uadec.edu.mx \\ 3 Departamento de Ciencia y Tecnología de Alimentos, Universidad Autónoma Agraria Antonio Narro, \\ Calzada Antonio Narro 1923, Col. Buena Ventura, C.P., Buenaventura, Coahuila 25315, Mexico; \\ labcta@hotmail.com \\ * Correspondence: ruthbelmares@uadec.edu.mx (R.B.); myke13_80@hotmail.com (M.C.)
}

Received: 22 January 2020; Accepted: 14 February 2020; Published: 19 February 2020

\begin{abstract}
Dough fermentation with lactic acid bacteria has been extensively studied due to the associated health benefits and its effects on physical and rheology parameters in dough and bread. However, most of the studies rely on long fermentation times. The aim of this study is to evaluate the effect of short fermentation times $(0$ to $8 \mathrm{~h})$ with Lactobacillus paracasei in rheology, physical and chemical properties on cassava dough and biscuits. Both storage modulus and loss modulus decreased as the fermentation times increased, down to 54,206.67 $\pm 13,348$ and 17,453.89 $\pm 3691 \mathrm{~Pa}$, respectively. Fermentation with $L$. paracasei influenced biscuit's hardness and chemical properties, and gas cell sizes were increased notably. These results suggest that short fermentation times could be used to improve dough's rheological characteristics.
\end{abstract}

Keywords: gluten-free; cassava; fermentation; storage modulus; loss modulus; Lactobacillus paracasei

\section{Introduction}

Bread and biscuits are among the most popular foodstuffs worldwide [1]. Gluten is the protein complex involved in the development of bread's volume and springiness. Structurally, gluten provide the network in which starch will gelatinize during baking, leading to bread's most common physical characteristics [2]. However, a significant amount of the worldwide population is not able to consume products containing this protein complex.

Celiac disease is an autoimmune disorder which shows gluten intolerance. Characteristic symptoms are chronic inflammation and atrophy of intestinal villi, impairing digestion and absorption processes [3]. Therefore, there is an increasing demand for gluten free (GF) products due to the attention celiac disease is receiving worldwide. There are several approaches researchers have taken to develop GF products, they vary from complex ones like using proteases to lower gluten content [4] to simpler ones such as using GF flours from alternative sources such as rice, chestnut and cassava [5-7].

Cassava (Manihot esculenta), which has been used in several foodstuffs including bread, is one of the most economical sources of carbohydrates and energy and its production is increasing [8]. 
Due to its high carbohydrate content, it could be used potentially as a sourdough substrate to improve physical and nutritional characteristics of products made from cassava.

Sourdough fermentation with lactic acid bacteria (LAB) has been reported to provide several health enhancing components such as $\gamma$-aminobutyric acid [9] and to modify rheological and physical characteristics of GF products [10]. However, one of sourdough's downsize presently is the high amount of time consumed during fermentation.

Several LAB have been employed in the development of sourdough, most commonly Lactobacillus plantarum. However, L. paracasei has seen increasing interest due to its health benefits on colon cancer [11] and for its use as sourdough starter [12].

The objective of this work is to evaluate the effect, in rheology, physical and chemical properties, on dough and biscuits fermented with L. paracasei for short fermentation times, in order to assess a faster method of enhancing biscuit's physical characteristics.

\section{Materials and Methods}

Fresh cassava tubers and commercial calcium enriched agave's inulin (enature ${ }^{\circledR}$ ) were bought in a local supermarket in Saltillo, Coahuila, Mexico.

\subsection{Flour Production}

Cassava tubers were washed, peeled and chopped into pieces. The pieces were dried in an air oven at $80^{\circ} \mathrm{C}$ during $48 \mathrm{~h}$. Afterwards, they were milled using a Pulvex Mini100 mill and screened into a maximum particle size of $0.42 \mathrm{~mm}$. Cassava flour was stored in sealed glass bottles at room temperature until use.

\subsection{Dough Fermentation}

Dough fermentation was carried out using L. paracasei obtained through local supplier Abiasa México S.A. de C.V. in a $1 \times 10^{8} \mathrm{CFU} / \mathrm{g}$ of flour concentration.

Probiotics were reactivated in water at $37^{\circ} \mathrm{C}$ for $5 \mathrm{~min}$ following manufacturer's instructions. Five different fermentation times were selected, $(0,2,4,6$ and $8 \mathrm{~h})$. The formulation used contains (all per $100 \mathrm{~g}$ cassava flour): $9.6 \mathrm{~g}$ of whole egg, $1.1 \mathrm{~g}$ of sodium bicarbonate, $0.3 \mathrm{~g}$ of salt, $84 \mathrm{~g}$ of water and $50 \mathrm{~g}$ of an animal fat source ( $34 \mathrm{~g}$ fats, $35 \mathrm{~g}$ water, $28 \mathrm{~g}$ protein, $3.5 \mathrm{~g}$ carbohydrates, all per $100 \mathrm{~g}$ of animal fat source).

$\mathrm{pH}$ was measured to assure the development of probiotics in the dough according to the Mexican normative NMX-F-317-S-1978 [13].

Doughs were fermented in an GI2-2 Shel Lab General purpose incubator at $37^{\circ} \mathrm{C}$.

\subsection{Dough and Biscuit Preparation}

After fermentation and homogenization, dough balls were shaped and weighted into three equal parts. Biscuits were baked at $180^{\circ} \mathrm{C}$ for $20 \mathrm{~min}$ in a San Son HCX Plus 3 convection oven. After baking, biscuits were left to cool at room temperature for $30 \mathrm{~min}$. After cooling, color, hardness and moisture tests were performed. Biscuits were then dried at $35^{\circ} \mathrm{C}$ in an air oven for $24 \mathrm{~h}$, grinded and stored in light protected sealed glass bottles at room temperature until use.

\subsection{Rheological Assays}

Doughs were analyzed in a Physica MCR 501 oscillatory rheometer according to the procedure described [14], with some modifications using a parallel plate geometry at $25^{\circ} \mathrm{C}$ with a probe diameter of $25 \mathrm{~mm}$ and gap of $0.5 \mathrm{~mm}$. Readings were taken for storage modulus $\left(\mathrm{G}^{\prime}\right)$ and loss modulus $\left(\mathrm{G}^{\prime \prime}\right)$ in the linear viscoelastic region during an angular frequency sweep $(\omega)$ ranging from $0-1001 / \mathrm{s}$. All assays were conducted by triplicate. The damping factor $(\tan \delta)$ was calculated using the following formula: 


$$
\tan \delta=\frac{G^{\prime \prime}}{G^{\prime}}
$$

The shear stress $(\tau)$ was calculated using the following formula:

$$
\tau=\frac{3 T}{2 \pi R^{3}}
$$

where $\mathrm{T}=$ torque and $\mathrm{R}=$ probe's radium.

\subsection{Physical Assays}

Biscuit's color values were obtained by using a 3nh NR2OXE Precision colorimeter. The scanning was performed at the center of the biscuit by triplicate, obtaining the mean of lightness $\left(\mathrm{L}^{*}\right)$, redness $\left(a^{*}\right)$ and yellowness $\left(b^{*}\right)$ values. Hardness was determined by using an EXTECH FHT200 Penetrometer on freshly baked biscuits using a probe of $3 \mathrm{~mm}$. The test was conducted at the center of the biscuits obtaining the mean in newtons $(\mathrm{N})$. All tests were conducted by triplicate.

\subsection{Chemical Composition Evaluation}

All assays were conducted by triplicates. Crude fiber, fat, ash and protein content were determined by A.O.A.C. 14.111, 14.019, 14.103 and 14.108 methods, while carbohydrate content was obtained using FAO's differential method [15]. Moisture was determined by using an MB23 Ohaus thermobalance; conditions were set to $110^{\circ} \mathrm{C}$ during 10 min with $0.5 \mathrm{~g}$ of sample.

\subsection{Experimental Design and Statistical Analyzes}

A completely randomized design was applied to evaluate all parameters along with the different fermentation times. An analysis of variance (ANOVA) was performed along with Tukey's tests to establish statistically significant differences between means of all variables. Analyses were performed in InfoStat ver. 2015e statistical software with a significance level $(\alpha)$ of 0.05 .

\section{Results and Discussion}

\subsection{Dough Fermentation}

In Figure 1, pH results of the fermented doughs are presented. The main objective of this study was to use reduced fermentation times for easier scaling up to industrial applications. $\mathrm{pH}$ was measured every $2 \mathrm{~h}$ from 0 to 6 with a final measurement at $24 \mathrm{~h}$ to evaluate Lactobacillus paracasei fermentation.

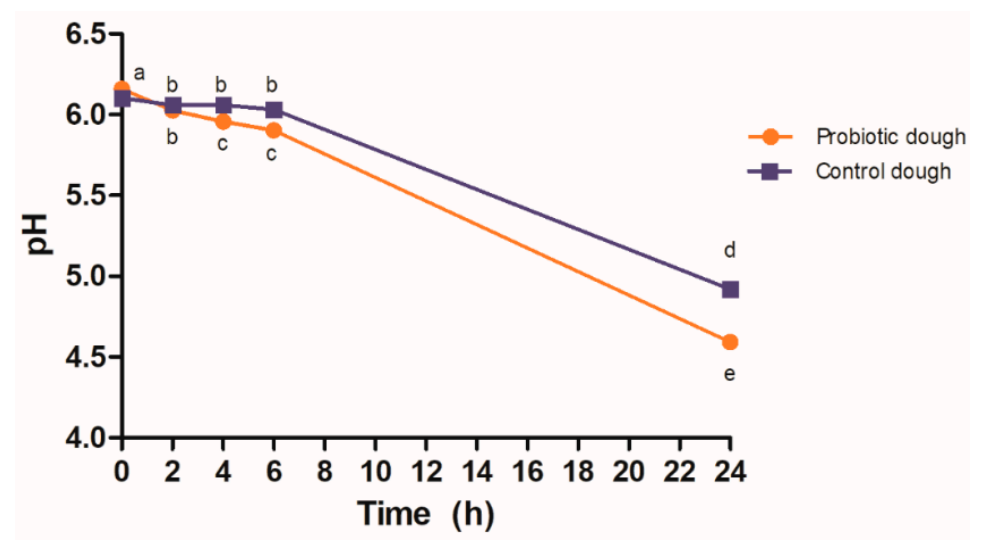

Figure 1. $\mathrm{pH}$ values for dough fermentation; data is mean ( \pm standard deviation) of three replicates. a, $b, c, d$, e different letters indicate significant differences $(p<0.05)$. 
Statistically significant differences between control dough and fermentation dough can be seen parting from $4 \mathrm{~h}$ of fermentation, being $6.06 \pm 0.00$ and $5.95 \pm 0.005$. Reducing processing times, while providing health benefits, could be of interest in the food industry. Other authors have reported lower $\mathrm{pH}$ values obtained after a $24 \mathrm{~h}$ fermentation, these values being 2.90 and 3.5, respectively [16,17]; while in this study, the $\mathrm{pH}$ values obtained were $4.59 \pm 0.005$ and $4.92 \pm 0.00$, respectively, for fermented and control dough. Direct comparisons are difficult, because the elements employed, such as flour source, probiotic microorganisms and its concentration, are different. Generally speaking, a lower $\mathrm{pH}$ value is desirable since it is used as an indirect indicator of microorganism proliferation and thus higher biotransformation of health beneficial compounds, as well as dough's rheology modification.

Control dough $\mathrm{pH}$ results suggest that natural cassava's microbiota could be fermenting carbohydrates present in the flour, however, not achieving the same results as the probiotic dough. Several lactic acid bacteria have been reported to be commonly found in cassava, such as L. plantarum, L. amylolyticus and L. mannihotivorans [18-20]. As far as we are concerned, there are no reports of an antagonistic effect between L. paracasei and the most common LAB in cassava. They have even been used together in other foodstuffs [21]. This suggests that $\mathrm{pH}$ differences can be attributed to L. paracasei inoculation used during this study.

L. plantarum has shown to be one of the lactic acid bacteria to adapt easily to cassava sourdough fermentation [22]. However, to the best of our knowledge, there is no study making a comparison in cassava sourdough between L. plantarum and L. paracasei.

\subsection{Rheology Assays}

$\overline{\mathrm{G}}^{\prime}$ provides information about the deformation energy stored in the sample. A higher value in this parameter means a higher elastic or solid-like behavior; while $\overline{\mathrm{G}}^{\prime \prime}$, on the contrary, is the energy lost and the sample does not regain its original shape due to its viscous behavior [23].

One of the main concerns involving GF products are the issues associated with high carbohydrate concentrations as well as low protein ones, especially gluten. This could often lead to lower quality products due to poor development during proofing [24]. Lower $G^{\prime}$ values are desired when considering doughs for bread and similar products, while higher ones are desired for cookies and cookie-like products. These values could serve as a predictive indicator of the suitability of the dough to be used for a specific type of product.

In Figures 2 and 3 the results for the trend in storage and loss modulus are presented. In this work, $\overline{\mathrm{G}}^{\prime}$ was higher than $\overline{\mathrm{G}}^{\prime \prime}$ in all fermentation times used. This falls in line with what has been seen in different gluten-free biscuits [14,25]. A decline can be observed in both $\overline{\mathrm{G}}^{\prime}$ and $\overline{\mathrm{G}}^{\prime \prime}$ along the increase of fermentation time. One possible explanation is $\mathrm{pH}$. Dough acidification impacts chemical components in the food matrix, allowing better interaction between water molecules and structure-forming components such as proteins and starch [14]. These results are similar to those found in a study using a traditional sourdough bread where an increase of moisture was found by acidifying the dough $[19,26]$.

In both Figures 2 and 3, an increase in both $\mathrm{G}^{\prime}$ and $\mathrm{G}^{\prime \prime}$ respectively can be observed as the angular frequency increases. This behavior has been reported in another study [14] and attributed to increased dough structure. In both cases, fermented doughs have a noticeably different trend compared to control dough $(0 \mathrm{~h})$. Authors often explain this behavior by the amount of organic acids produced during fermentation [14].

Doughs present weak gel-like behavior according to the tan $\delta$ values shown in Figure 4 (6 h and $8 \mathrm{~h}$ ), while $2 \mathrm{~h}, 4 \mathrm{~h}$ and $6 \mathrm{~h}$ are right in the boundary between a weak gel and an excess of structuring components [24]. Similarly, this could be caused by the acidification of the dough, allowing better interaction between water and other molecules present, as previously mentioned. The decline of $\tau$ indicates that dough opposes less resistance as the fermentation time increases, meaning that doughs start exhibiting a decreased elastic behavior compared to control. This has been discussed in 
another study where it was found that sourdoughs have lower shear stress values compared to regular doughs [27].

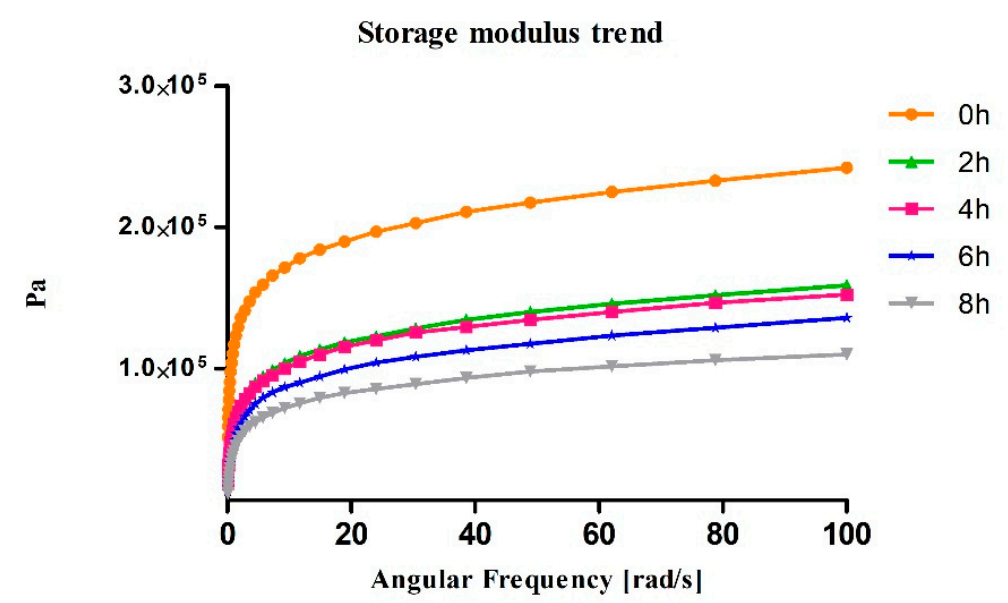

Figure 2. Storage modulus trends obtained through the rheology assay in fermented doughs.

Loss modulus trend

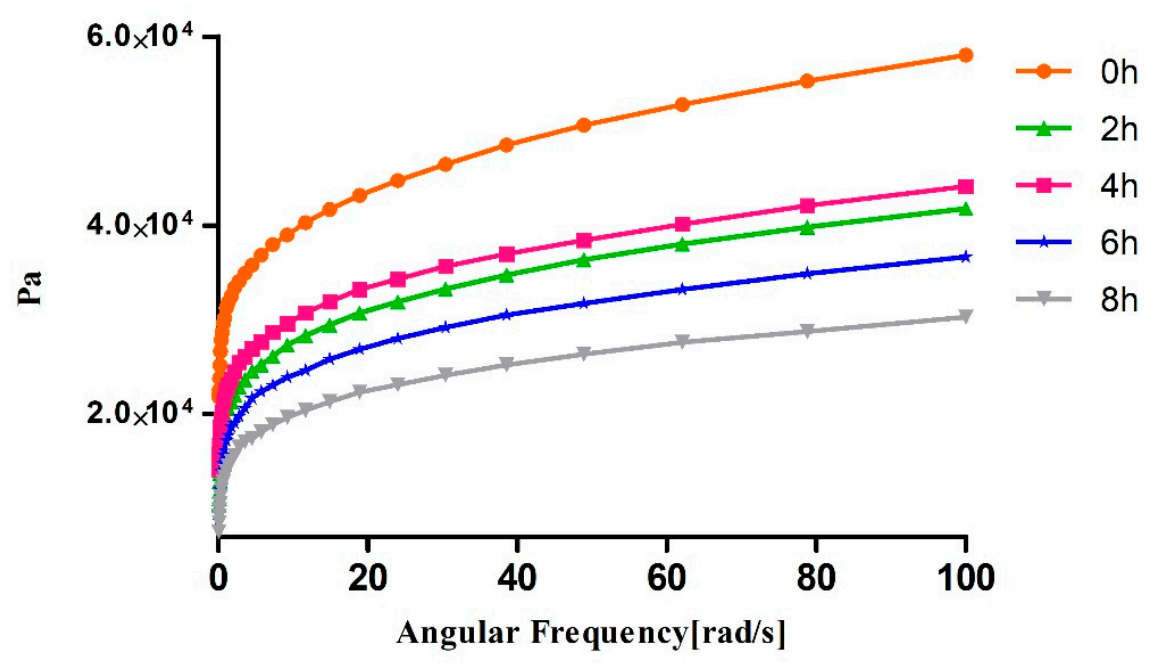

Figure 3. Loss modulus trends obtained through the rheology assay in fermented doughs.

\section{Damping factor trend}

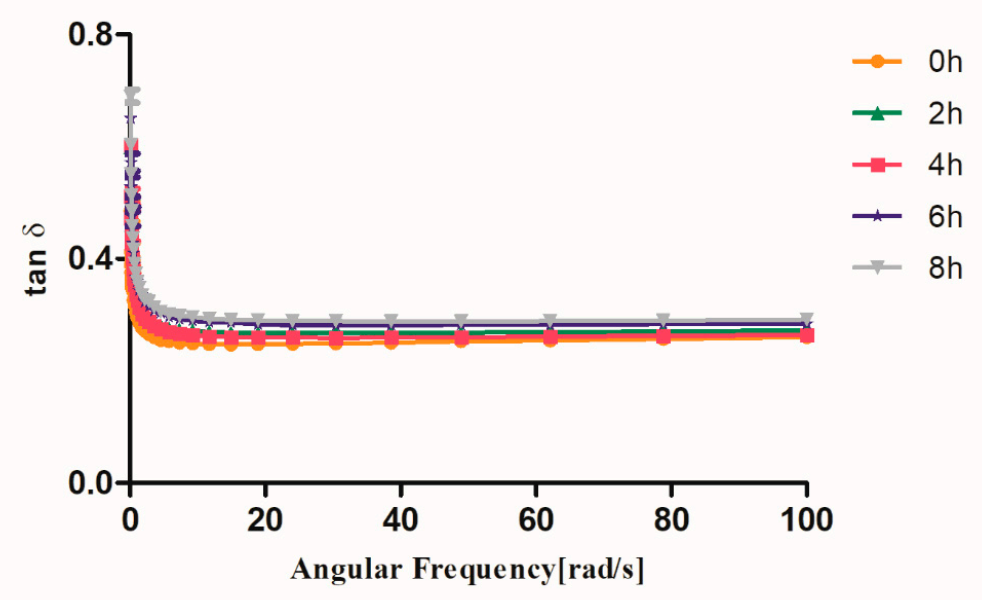

Figure 4. Damping factor trends obtained through the rheology assay in fermented doughs. 


\subsection{Physical Assay}

Hardness values obtained from sourdough bread often show mixed results. It has been seen on wheat bread that sourdough addition increases bread's hardness [28]. However, it has also been reported that sourdough addition lowers hardness values [29]. Often, high hardness values have been observed in GF products, generally due to the high amount of carbohydrates present in the food matrix [24]. Regarding GF bread, hardness results also often show mixed results. Addition of fermented Lupinus angustifolius L. flour $(3 \mathrm{~g} / 100 \mathrm{~g}, 6 \mathrm{~g} / 100 \mathrm{~g})$ increased bread's hardness by $34 \%$ and $17 \%$, respectively [30]. Fermented cassava flour has been correlated to increased bread hardness [31]. Hardness results obtained can be observed in Figure 5. All biscuits showed similar results, except for $2 \mathrm{~h}$ and $6 \mathrm{~h}$, both being statistically different from each other. Surface response methodology has been used to identify trends in physical and rheological properties of breads. Bread hardness indicated that there is an optimum fermentation time window in which a maximum or minimum value is obtained [32]. Hardness values for $2 \mathrm{~h}$ and $6 \mathrm{~h}$ could be explained by a similar behavior, $2 \mathrm{~h}$ being the maximum value obtained and $6 \mathrm{~h}$ the minimum value. Larger cell size formation during baking would have a significant impact on bread's hardness. As seen in Table 1, carbohydrate content decreased while hardness values were maintained in control biscuit and fermented flour biscuit. This can be explained primarily by the baking temperature and moisture content in the food matrix. It has been reported that these two values have a positive correlation on bread crumb's hardness [33].

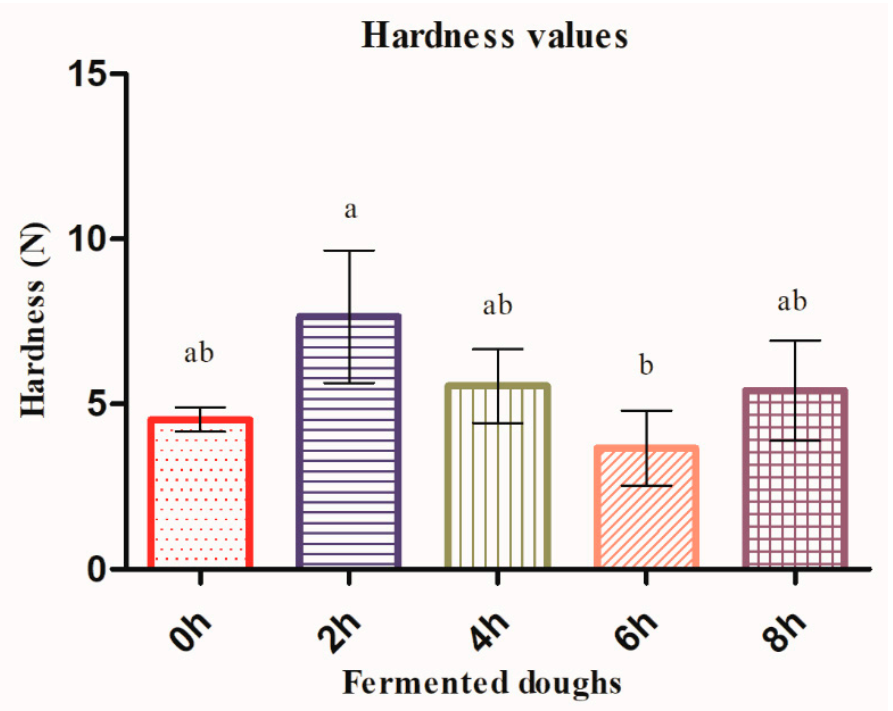

Figure 5. Hardness values obtained in biscuits made from fermented flour. Data is mean of three replicates ( \pm standard deviation). $\mathbf{a}, \mathbf{b}$ different letters indicate significant differences $(p<0.05)$.

Table 1. Results of chemical composition analyzes obtained from biscuits from flours fermented for different amounts of time. Data is mean of three replicates ( \pm standard deviation). a, b different letters indicate significant differences within the same column $(p<0.05)$.

\begin{tabular}{ccccccc}
\hline Fermentation Time & Crude Fiber (\%) & Fats (\%) & Carbohydrates (\%) & Ash (\%) & Protein (\%) & Moisture (\%) \\
\hline $0 \mathrm{~h}$ & $0.40 \pm 0.05^{\mathrm{a}}$ & $8.66 \pm 1.66^{\mathrm{b}}$ & $56.76 \pm 3.16^{\mathrm{a}}$ & $0.08 \pm 0.03^{\mathrm{a}}$ & $9.43 \pm 0.64^{\mathrm{a}}$ & $24.6 \pm 2.31^{\mathrm{a}}$ \\
\hline $2 \mathrm{~h}$ & $0.68 \pm 0.02^{\mathrm{a}}$ & $14.3 \pm 1.08^{\mathrm{a}}$ & $32.9 \pm 1.71^{\mathrm{b}}$ & $4.63 \pm 0.09^{\mathrm{b}}$ & $12.2 \pm 2.08^{\mathrm{a}}$ & $35.1 \pm 1.01^{\mathrm{b}}$ \\
\hline $4 \mathrm{~h}$ & $0.57 \pm 0.05^{\mathrm{a}}$ & $14.2 \pm 0.45^{\mathrm{a}}$ & $29.4 \pm 7.27^{\mathrm{b}}$ & $4.82 \pm 0.14^{\mathrm{b}}$ & $12.2 \pm 1.13^{\mathrm{a}}$ & $38.6 \pm 6.43^{\mathrm{b}}$ \\
\hline $6 \mathrm{~h}$ & $0.40 \pm 0.07^{\mathrm{a}}$ & $13.2 \pm 0.84^{\mathrm{a}}$ & $35.4 \pm 1.10^{\mathrm{b}}$ & $4.79 \pm 0.10^{\mathrm{b}}$ & $10.8 \pm 0.35^{\mathrm{a}}$ & $35.3 \pm 1.15^{\mathrm{b}}$ \\
\hline $8 \mathrm{~h}$ & $0.42 \pm 0.02^{\mathrm{a}}$ & $12.4 \pm 0.16^{\mathrm{a}}$ & $38.0 \pm 1.52^{\mathrm{b}}$ & $4.76 \pm 0.13^{\mathrm{b}}$ & $10.7 \pm 2.16^{\mathrm{a}}$ & $33.5 \pm 0.40^{\mathrm{b}}$ \\
\hline
\end{tabular}

Both cell number and size changed considerably when comparing to the control biscuit, as can be seen in Figure 6. It has been seen that, with the use of sourdoughs, bread crumb gas cell size increases. However, a transglutaminase (TG) was used to increase fermentation stability [34]. It is 
thought that dough acidification could have a direct impact in gas cell formation and size by modifying the interaction between water and other molecules within the food matrix [35]. The decrease of $\overline{\mathrm{G}}^{\prime}$ could be the best explanation for this. It has been observed that the viscous portion of dough mass allows gas cells to expand [36].

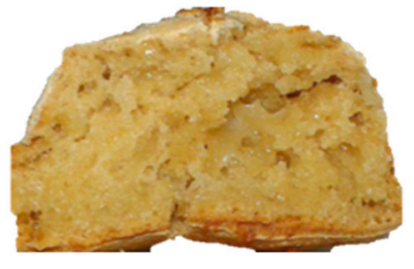

Oh

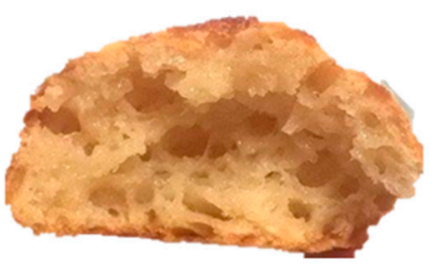

4h

Figure 6. Picture of transversal cut of two of the baked biscuits. $0 \mathrm{~h}$ control biscuit, $4 \mathrm{~h}$ biscuit made from flour fermented for $4 \mathrm{~h}$.

In terms of color, there was no statistical difference in the parameters as can be seen in Table 1. However, there exists a browning effect with a statistical difference between $0 \mathrm{~h}$ (blank) and the rest of the biscuits. Contrary results have been obtained where flour formulations were substituted with fermented chestnut flour [6]. L* values ranged from 56.70 to 50.33 increasing along with the chestnut sourdough substitution. However, fermentation times were considerably higher $(120 \mathrm{~h})$ than those used in this paper. Similarly, $\mathrm{L}^{*}$ values for biscuits made with fermented Agaricus bisporus polysaccharides showed a significant difference between their treatments [14]. $L^{*}$ values obtained in this investigation could be explained by the fat content along with maillard reactions [14,32].

\subsection{Chemical Composition Assays}

Results of chemical composition analyses are shown in Table 2. An increase in fat content can be seen by a comparison against $0 \mathrm{~h}$. It has been reported that $L$. paracasei is capable of producing short-chained fatty acids (SCFA). However, levels seen are in the mmol $/ \mathrm{kg}$ order and in human feces [38]. To the best of our knowledge the highest production of SCFA seen in a sourdough model has peaked at $360 \mathrm{mg} / \mathrm{kg}$ [39]. Seeing that there is no statistical difference between treatments, these results suggest that the commercial formulation of the lactic acid bacteria contains an additive. Further studies out of the scope of this work should be carried on determining if there was a production of SCFA.

Table 2. Biscuit color analysis results from different fermentation times $\mathrm{a}, \mathrm{b}$ different letters indicate significant differences within the same column $(p<0.05)$.

\begin{tabular}{cccc}
\hline \multirow{2}{*}{ Fermentation Time } & \multicolumn{3}{c}{ Color } \\
\cline { 2 - 4 } & $\mathbf{L}^{*}$ & $\mathbf{a}^{*}$ & $\mathbf{b}^{*}$ \\
\hline $\mathbf{0 ~ h}$ & $73.92 \pm 3.88^{\mathrm{a}}$ & $13.78 \pm 1.41^{\mathrm{a}}$ & $33.14 \pm 1.43^{\mathrm{a}}$ \\
\hline $\mathbf{2} \mathbf{~ h}$ & $54.99 \pm 3.17^{\mathrm{b}}$ & $18.39 \pm 1.71^{\mathrm{a}}$ & $30.92 \pm 1.73^{\mathrm{a}}$ \\
\hline $\mathbf{4} \mathbf{h}$ & $54.88 \pm 2.16^{\mathrm{b}}$ & $20.12 \pm 1.51^{\mathrm{a}}$ & $32.65 \pm 1.12^{\mathrm{a}}$ \\
\hline $\mathbf{6} \mathbf{h}$ & $51.71 \pm 3.28^{\mathrm{b}}$ & $19.20 \pm 2.65^{\mathrm{a}}$ & $30.96 \pm 2.73^{\mathrm{a}}$ \\
\hline $\mathbf{8} \mathbf{h}$ & $52.28 \pm 8.64^{\mathrm{b}}$ & $19.69 \pm 4.63^{\mathrm{a}}$ & $30.66 \pm 0.54^{\mathrm{a}}$ \\
\hline
\end{tabular}

In both $\mathrm{a}^{*}$ and $\mathrm{b}^{*}$ there was no significant difference between $0 \mathrm{~h}$ and treatment biscuits. These results suggest that in order to see significant changes in color, longer fermentation times should be employed as in other works $[6,14,37]$.

Ash content could be explained in a similar manner. Following $L^{*}$ results from Table 1, maillard reactions decreased biscuit's lightness which could explain the difference between ash content in control biscuit $(0 \mathrm{~h})$ and those made from fermented flours. 
Noticeably, there is no statistical difference between treatments in protein content. This differs from the scientific literature, where it has been seen that flour fermentation with lactic acid bacteria has an effect on both amino acid and protein content [40]. It has been seen that fermentation can significantly increase crude protein content and be detected by the assays done in this paper [41]. However, fermentations last considerably longer in research $(72 \mathrm{~h})$.

\section{Conclusions}

Fermentation of cassava flour with L. paracasei had an effect on moisture and fat content. Results obtained showed significant differences in chemical properties, which had an impact on the measured rheology properties leading to increased cell size. Hardness values suggest that there is an optimal fermentation time for this property, as previously reported. These results suggest that short fermentation times with $L$. paracasei could be used to improve the rheological characteristics of cassava GF doughs leading to better physical attributes. Fermentation for just $4 \mathrm{~h}$ in cassava flour with $L$. paracasei, was enough to show important effects in gas cell size. Nevertheless, longer fermentation times have a significant impact on the nutritional quality of the doughs and biscuits, which should be considered when developing sourdough biscuits seeking enhanced health benefits.

Author Contributions: Conceptualization, S.L. and R.B.; methodology, S.L.; validation, J.C., M.F.; formal analysis, S.L.; investigation, S.L.; resources, M.C., R.B.; writing-Original draft preparation, S.L.; writing-Review and editing, R.B., M.C., M.F.; visualization, J.C.; supervision, R.B.; project administration, R.B.; funding acquisition, S.L., R.B. All authors have read and agreed to the published version of the manuscript.

Funding: This research was funded by the Mexican Consejo Nacional de Ciencia y Tecnología through a graduate studies scholarship.

Acknowledgments: S.L.-G. would like to thank every mentor and colleague at Universidad Autónoma de Coahuila.

Conflicts of Interest: The authors declare no conflicts of interest.

\section{References}

1. Nagi, H.P.S.; Kuar, J.; Dar, B.N.; Sharma, S. Effect of Storage Period and Packaging on the Shelf Life of Cereal Bran Incorporated Biscuits. Am. J. Food Technol. 2012, 7, 301-310.

2. Cauvain, S. Technology of Breadmaking, 3rd ed.; Springer International Publishing: Witney, UK, 2015; pp. 306-309.

3. Morais, E.C.; Cruz, A.G.; Faria, J.A.F.; Bolini, H.M.A. Prebiotic gluten-free bread: Sensory profiling and drivers of liking. LWT Food Sci. Technol. 2014, 55, 248-254. [CrossRef]

4. Scherf, K.A.; Wieser, H.; Koehler, P. Novel approaches for enzymatic gluten degradation to create high-quality gluten-free products. Food Res. Int. 2016, 110, 62-72. [CrossRef] [PubMed]

5. Matos, M.E.; Rosell, C.M. Quality Indicators of Rice-Based Gluten-Free Bread-Like Products: Relationships between Dough Rheology and Quality Characteristics. Food Bioprocess Technol. 2013, 6, 2331-2341. [CrossRef]

6. Aguilar, N.; Albanell, E.; Miñarro, B.; Capellas, M. Chestnut flour sourdough for gluten-free bread making. Eur. Food Res. Technol. 2016, 242, 1795-1802. [CrossRef]

7. Pasqualone, A.; Caponio, F.; Summo, C.; Paradiso, V.M.; Bottega, G.; Pagani, M.A. Gluten-Free Bread Making Trials from Cassava (Manihot esculenta crantz) Flour and Sensory Evaluation of the Final Product. Int. J. Food Prop. 2010, 13, 562-573. [CrossRef]

8. Reinhardt, H.; NeBambi, L.; Graeme, T. Save and Grow Cassava a Guide to Sustainable Production Intensification; FAO: Rome, Italy, 2013; pp. 30-31.

9. Peñas, E.; Diana, M.; Frias, J.; Quílez, J.; Martínez-Villaluenga, C. A Multistrategic Approach in the Development of Sourdough Bread Targeted Towards Blood Pressure Reduction. Plant Foods Hum. Nutr. 2015, 70, 97-103. [CrossRef]

10. Wolter, A.; Hager, A.-S.; Zannini, E.; Czerny, M.; Arendt, E.K. Impact of sourdough fermented with Lactobacillus plantarum FST 1.7 on baking and sensory properties of gluten-free breads. Eur. Food Res. Technol. 2014, 239, 1-12. [CrossRef] 
11. Huang, L.; Shan, Y.-J.; He, C.-X.; Ren, M.-H.; Tian, P.-J.; Song, W. Effects of L. paracasei subp. paracasei X12 on cell cycle of colon cancer HT-29 cells and regulation of mTOR signalling pathway. J. Funct. Foods 2016, 21, 431-439. [CrossRef]

12. Mantzourani, I.; Plessas, S.; Odatzidou, M.; Alexopoulos, A.; Galanis, A.; Bezirtzoglou, E.; Bekatorou, A. Effect of a novel Lactobacillus paracasei starter on sourdough bread quality. Food Chem. 2019, 271, $259-265$. [CrossRef]

13. Dirección General de Normas. Determinacion de pH en Alimentos; Gobierno Federal Mexicano: Mexico City, Mexico, 1978; pp. 3-6.

14. Sulieman, A.A.; Zhu, K.X.; Peng, W.; Hassan, H.A.; Obadi, M.; Siddeeg, A.; Zhou, H.M. Rheological and quality characteristics of composite gluten-free dough and biscuits supplemented with fermented and unfermented Agaricus bisporus polysaccharide flour. Food Chem. 2019, 271, 193-203. [CrossRef] [PubMed]

15. WHO/FAO. Food Energy Methods of Analysis and Conversion Factors; WHO: Geneva, Switzerland; FAO: Rome Italy, 2002; p. 12.

16. Dastmalchi, F.; Razavi, S.H.; Faraji, M.; Labbafi, M. Effect of Lactobacillus casei- casei and Lactobacillus reuteri on acrylamide formation in flat bread and Bread roll. J. Food Sci. Technol. 2016, 53, 1531-1539. [CrossRef] [PubMed]

17. Paucean, A.; Vodnar, D.C.; Socaci, S.A.; Socaciu, C. Carbohydrate metabolic conversions to lactic acid and volatile derivatives, as influenced by Lactobacillus plantarum ATCC 8014 and Lactobacillus casei ATCC 393 efficiency during in vitro and sourdough fermentation. Eur. Food Res. Technol. 2013, 237, 679-689. [CrossRef]

18. Guyot, J.P.; Morlon-Guyot, J. Effect of different cultivation conditions on Lactobacillus manihotivorans OND32T, an amylolytic lactobacillus isolated from sour starch cassava fermentation. Int. J. Food Microbiol. 2001, 67, 217-225. [CrossRef]

19. Torrieri, E.; Pepe, O.; Ventorino, V.; Masi, P.; Cavella, S. Effect of sourdough at different concentrations on quality and shelf life of bread. LWT Food Sci. Technol. 2014, 56, 508-516. [CrossRef]

20. Ramos, C.L.; Sousa, E.S.O.D.; Ribeiro, J.; Almeida, T.M.M.; Santos, C.C.A.D.A.; Abegg, M.A.; Schwan, R.F. Microbiological and chemical characteristics of tarubá, an indigenous beverage produced from solid cassava fermentation. Food Microbiol. 2015, 49, 182-188. [CrossRef] [PubMed]

21. Feng, L.; Xie, Y.; Peng, C.; Liu, Y.; Wang, H. A Novel Antidiabetic Food Produced via Solid-State Fermentation of Tartary Buckwheat using L. plantarum TK9 and L. paracasei TK1501. Food Technol. Biotechnol. 2018, 56, 3. [CrossRef] [PubMed]

22. Vogelmann, S.A.; Seitter, M.; Singer, U.; Brandt, M.J.; Hertel, C. Adaptability of lactic acid bacteria and yeasts to sourdoughs prepared from cereals, pseudocereals and cassava and use of competitive strains as starters. Int. J. Food Microbiol. 2009, 130, 205-212. [CrossRef] [PubMed]

23. Ashraf Khan, A.; Gani, A.; Masoodi, F.A.; Mushtaq, U.; Silotry Naik, A. Structural, rheological, antioxidant, and functional properties of $\beta$-glucan extracted from edible mushrooms Agaricus bisporus, Pleurotus ostreatus and Coprinus attrimentarius. Bioact. Carbohydr. Diet. Fibre 2017, 11, 67-74. [CrossRef]

24. Ronda, F.; Pérez-Quirce, S.; Villanueva, M. Rheological Properties of Gluten-Free Bread Doughs: Relationship with Bread Quality. In Advances in Food Rheology and Its Applications; Ahmed, J., Pstazek, P., Banu, S., Eds.; Elsevier: Amsterdam, The Netherlands, 2017; pp. 297-334.

25. Sarabhai, S.; Sudha, M.L.; Prabhasankar, P. Rheological characterization and biscuit making potential of gluten free flours. J. Food Meas. Charact. 2017, 11, 1449-1461. [CrossRef]

26. Rinaldi, M.; Paciulli, M.; Caligiani, A.; Sgarbi, E.; Cirlini, M.; Dall'Asta, C.; Chiavaro, E. Durum and soft wheat flours in sourdough and straight-dough bread-making. J. Food Sci. Technol. 2015, 52, 6254-6265. [CrossRef] [PubMed]

27. Elhassan, M.S.M.; Emmambux, M.N.; Taylor, J.R.N. Transgenic sorghum with suppressed synthesis of kafirin subclasses: Effects on flour and dough rheological characteristics. J. Cereal Sci. 2017, 75, 69-76. [CrossRef]

28. Olojede, A.O.; Banwo, K.; Sanni, A.I. Rheological, textural and nutritional properties of gluten-free sourdough made with functionally important lactic acid bacteria and yeast from Nigerian sorghum. LWT Food Sci. Technol. 2020, 120, 108875. [CrossRef]

29. Pontonio, E.; Nionelli, L.; Curiel, J.A.; Sadeghi, A.; Di Cagno, R.; Gobbetti, M.; Rizzello, C.G. Iranian wheat flours from rural and industrial mills: Exploitation of the chemical and technology features, and selection of autochthonous sourdough starters for making breads. Food Microbiol. 2015, 47, 99-110. [CrossRef] 
30. Klupsaite, D.; Juodeikiene, G.; Bartkiene, E.; Maknickiene, Z.; Liutkute, G.; Zadeike, D. The influence of lactic acid fermentation on functional properties of narrow-leaved lupine protein as functional additive for higher value wheat bread. LWT Food Sci. Technol. 2017, 75, 180-186. [CrossRef]

31. Monthe, O.C.; Grosmaire, L.; Nguimbou, R.M.; Dahdouh, L.; Riccie, J.; Tran, T.; Ndjouenkeu, R. Rheological and textural properties of gluten-free doughs and breads based on fermented cassava, sweet potato and sorghum mixed flours. LWT Food Sci. Technol. 2019, 101, 575-582. [CrossRef]

32. Abedfar, A.; Sadeghi, A. Response surface methodology for investigating the effects of sourdough fermentation conditions on Iranian cup bread properties. Heliyon 2019, 5, e02608. [CrossRef]

33. Shittu, T.; Raji, A.O.; Sanni, L.O. Bread from composite cassava-wheat flour: I. effect of baking time and temperature on some physical properties of bread loaf. Food Res. Int. 2007, 40, 280-290. [CrossRef]

34. Scarnato, L.; Montanari, C.; Serrazanetti, D.I.; Aloisi, I.; Balestra, F.; Del Duca, S.; Lanciotti, R. New bread formulation with improved rheological properties and longer shelf-life by the combined use of transglutaminase and sourdough. LWT Food Sci. Technol. 2017, 81, 101-110. [CrossRef]

35. Habibi Najafi, M.B.; Pourfarzad, A.; Zahedi, H.; Ahmadian-Kouchaksaraie, Z.; Haddad Khodaparast, M.H. Development of sourdough fermented date seed for improving the quality and shelf life of flat bread: Study with univariate and multivariate analyses. J. Food Sci. Technol. 2016, 53, 209-220. [CrossRef]

36. Rathnayake, H.A.; Navaratne, S.B.; Navaratne, C.M. Porous Crumb Structure of Leavened Baked Products. Int. J. Food Sci. 2018, 2018, 8187318. [CrossRef] [PubMed]

37. Sanz-Penella, J.M.; Tamayo-Ramos, J.A.; Haros, M. Application of Bifidobacteria as Starter Culture in Whole Wheat Sourdough Breadmaking. Food Bioprocess Technol. 2012, 5, 2370-2380. [CrossRef]

38. Cremon, C.; Guglielmetti, S.; Gargari, G.; Taverniti, V.; Castellazzi, A.M.; Valsecchi, C.; Tagliacarne, C.; Fiore, W.; Bellini, M.; Bertani, L.; et al. Effect of Lactobacillus paracasei CNCM I-1572 on symptoms, gut microbiota, short chain fatty acids, and immune activation in patients with irritable bowel syndrome: A pilot randomized clinical trial. United Eur. Gastroenterol. J. 2018, 6, 604-613. [CrossRef]

39. Axel, C.; Brosnan, B.; Zannini, E.; Peyer, L.C.; Furey, A.; Coffey, A.; Arendt, E.K. Antifungal activities of three different Lactobacillus species and their production of antifungal carboxylic acids in wheat sourdough. Appl. Microbiol. Biotechnol. 2016, 100, 1701-1711. [CrossRef] [PubMed]

40. Zannini, E.; Pontonio, E.; Waters, D.M.; Arendt, E.K. Applications of microbial fermentations for production of gluten-free products and perspectives. Appl. Microbiol. Biotechnol. 2012, 93, 473-485. [CrossRef]

41. Adebiyi, J.A.; Obadina, A.O.; Adebo, O.A.; Kayitesi, E. Comparison of nutritional quality and sensory acceptability of biscuits obtained from native, fermented, and malted pearl millet (Pennisetum glaucum) flour. Food Chem. 2017, 232, 210-217. [CrossRef] [PubMed]

(C) 2020 by the authors. Licensee MDPI, Basel, Switzerland. This article is an open access article distributed under the terms and conditions of the Creative Commons Attribution (CC BY) license (http://creativecommons.org/licenses/by/4.0/). 